\title{
Cytochemical Quantification of Physiologic Regulation of Oxyntic Cell Carbonic Anhydrase ${ }^{a}$
}

\author{
A. I. VINIK ${ }^{b}$ and A. A. HELDSINGER \\ Department of Internal Medicine \\ University of Michigan Medical School \\ Ann Arbor, Michigan 48109
}

\section{INTRODUCTION}

Although the primary function of carbonic anhydrase (CA) is to catalyze the hydration of $\mathrm{CO}_{2}$ to form carbonic acid, ${ }^{1}$ the abundance of $\mathrm{CA}$ in the gastric oxyntic cell ${ }^{2-4}$ has raised the question of the role of $\mathrm{CA}$ in acid secretion. In order to evaluate the physiologic regulation of $\mathrm{CA}$ in the guinea pig oxyntic cell, we studied the effects of three known acid secretagogues, gastrin, histamine, and carbamylcholine, on the activation of CA using quantitative cytochemistry.

\section{METHODS}

CA was measured by the technique utilized by Loveridge ${ }^{5}$ in segments and modified for quantitative cytochemical measurement of CA activity in $18 \mu \mathrm{m}$ sections of guinea pig fundic mucosa. ${ }^{6-8}$ Sections were cut from the mounted tissue in a cryostat at $-20^{\circ} \mathrm{C}$ and were mounted on glass slides. Test solutions $(100 \mu \mathrm{l})$ in $0.025 \mathrm{M}$ HEPES buffer at $\mathrm{pH} 7.0$ were delivered simultaneously to 24 sections and allowed to react at $20^{\circ} \mathrm{C}$ for $90 \mathrm{sec}$. The reaction was terminated by the addition of the staining reagents. Fifteen to twenty oxyntic cells in each of the randomized/coded sections were read at $550 \mathrm{~nm}$. Values for the density of the $\mathrm{CoS}$ precipitate in each section were read as integrated extinction and were expressed as a percent using the following equation: (mean extinction of oxyntic cells) - (mean extinction of muscularis) $\times 100 / \mathrm{D} 1$, where $\mathrm{D}$ is the reading of a standard filter with an optical density of 1 .

\section{RESULTS AND DISCUSSION}

The oxyntic cells were the most darkly stained. The coefficient of variation of the extinction readings taken on 20 cells in an unstimulated section varied from 4.1 to $7.8 \%$ and for cells stimulated by a $10^{-12} \mathrm{M}$ dose of gastrin was $4.6 \%$. Thus upon stimulation, all cells appeared to respond in an equivalent manner.

“ This work was supported by a grant from the National Institutes of Health (USPHS AM27077) and a Rackham Faculty Research Grant.

${ }^{b}$ Mail correspondence to: A. I. Vinik, M.D., D2226 SACB Box 046, Ann Arbor, MI 48109. 


\section{Time Study}

The response to stimulation was biphasic. The early peak response to gastrin, histamine, and carbamylcholine occurred at $90 \mathrm{sec}$ of exposure and a second at 240 seconds with persistance of the response thereafter. Removal of the incubate and reexposure to the secretagogues again caused an increase in CA activity similar to that found with the initial exposure. However, for these studies all subsequent experiments were carried out using $90 \mathrm{sec}$ of exposure time.

\section{Secretagogue Dose-response Curves}

Dose-response curves for CA activation by histamine, gastrin and carbamylcholine are shown in FIGURE 1. Gastrin had the greatest efficacy (100\%), histamine $68 \pm 4 \%$ and carbamylcholine $81 \pm 4 \%$ of the maximum response to gastrin.

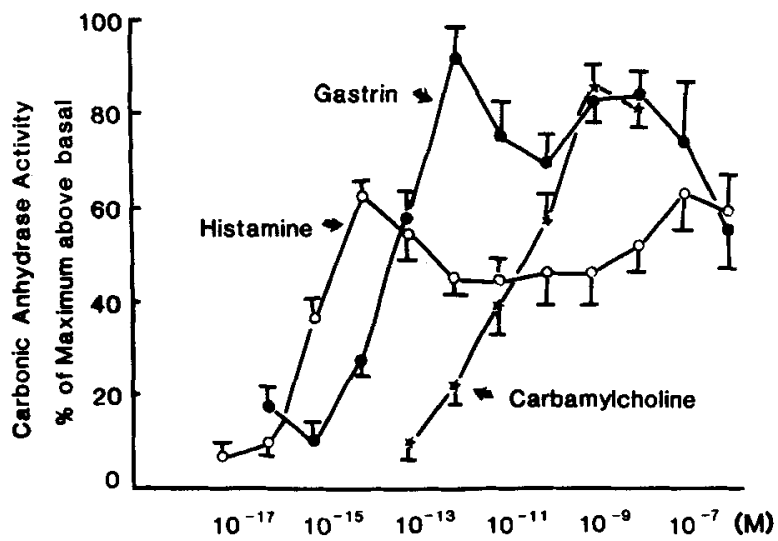

FIGURE 1. A comparison of the effects of histamine, gastrin and carbamylcholine on oxyntic cell carbonic anhydrase activity. The values are expressed as $\%$ of the maximum response to gastrin, which was arbitrarily ascribed a value of $100 \%$.

The doses required to produce half maximal effects $\left(D_{50}\right)$ were: histamine $=7.0 \times$ $10^{-16} \mathrm{M}$, gastrin $=3.0 \times 10^{-14} \mathrm{M}$ and carbamylcholine $=3.0 \times 10^{-11} \mathrm{M}$.

\section{Inhibition of CA Activity}

Addition of the CA inhibitor, acetazolamide $\left(10^{-5} \mathrm{M}\right)$ did not affect basal CA activity, but abolished the effects of gastrin $(p<0.025)$ and histamine $(p<0.001)$ stimulated activity. Cimetidine $\left(10^{-5} \mathrm{M}\right)$ reduced by $75 \%$ the effects of histamine but that of gastrin by only $25 \%$. Atropine had no effects on the response to gastrin or histamine, but virtually abolished the actions of carbamylcholine (FIG. 2). The stimulation of CA activity by all three secretagogues was inhibited by $10^{-3} \mathrm{M}$ of both NaSCN and H149/94 (FIG. 3). 
We have shown that the acid secretagogues activate CA within 90 seconds. The reason for the inordinate sensitivity is not clear, but it contrasts with the effect of direct stimulation of isolated bovine red cell $\mathrm{CA}$, which required larger concentrations $\left(10^{-6} \mathrm{M}-10^{-7} \mathrm{M}\right)$ of secretagogues ${ }^{9}$ than those used here, suggesting that an amplification system within the cell was present. The response is biphasic. It is not clear at present whether the factors regulating the different phases are the same. The selective effects of inhibitors suggest that the activation of CA by the three agonists is mediated by separate receptors for histamine, carbamylcholine, and gastrin. ${ }^{10}$

It is evident that a number of close parallels may be drawn between activation of $\mathrm{CA}$ activity in the sections of oxyntic cells and acid secretion. Hersey ${ }^{11}$ suggested that the function of $\mathrm{CA}$ is to act as a buffer to maintain intracellular $\mathrm{pH}$ during acid secretion. Activation of CA by all three gastric acid secretagogues was inhibited by acetazolamide, indicating that they activate CA. H149/94, a substituted benzimidazole inhibits the $\mathrm{H}^{+}+\mathrm{K}^{+}$-ATPase as well as acid secretion. ${ }^{12}$ In our studies, inhibition of secretagogue-stimulated $\mathrm{CA}$ activity was achieved by $10^{-3} \mathrm{M}-10^{-5} \mathrm{M} \mathrm{H} 149 / 94$, suggesting that the action of secretagogues on CA may be linked to the $\mathrm{H}^{+}+\mathrm{K}^{+}-$ATPase. ${ }^{12}$ Although these data do not prove a cause and effect relationship between $\mathrm{CA}$ and acid secretion, they suggest that intracellular events initiated by receptor stimulation may modify CA activation in the same manner that they affect acid secretion.

\section{SUMMARY}

We have studied the physiologic factors regulating oxyntic cell activity using cytochemical quantification of carbonic anhydrase (CA) activity. Gastrin $\left(10^{-16}\right.$ to $\left.10^{-12} \mathrm{M}\right)$, histamine $\left(10^{-17}\right.$ to $\left.10^{-13} \mathrm{M}\right)$, and carbamylcholine $\left(10^{-13}\right.$ to $\left.10^{-8} \mathrm{M}\right)$ caused a dose-dependent increase in CA in the oxyntic cells in guinea pig gastric fundus, maximal at $90 \mathrm{sec}$. The stimulation of $\mathrm{CA}$ by all three secretagogues was

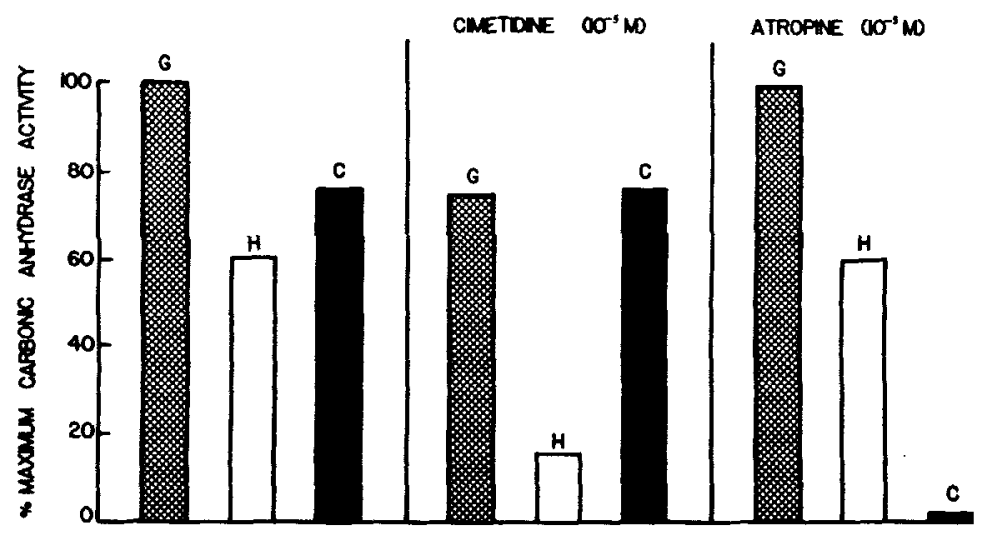

FGURE 2. Carbonic anhydrase activity of tissues reacted with gastrin (G), histamine (H), or carbamylcholine $(C)$ alone and in the presence of the $\mathrm{H}_{2}$-blocker cimetidine and the muscarinic cholinergic antagonist atropine. 


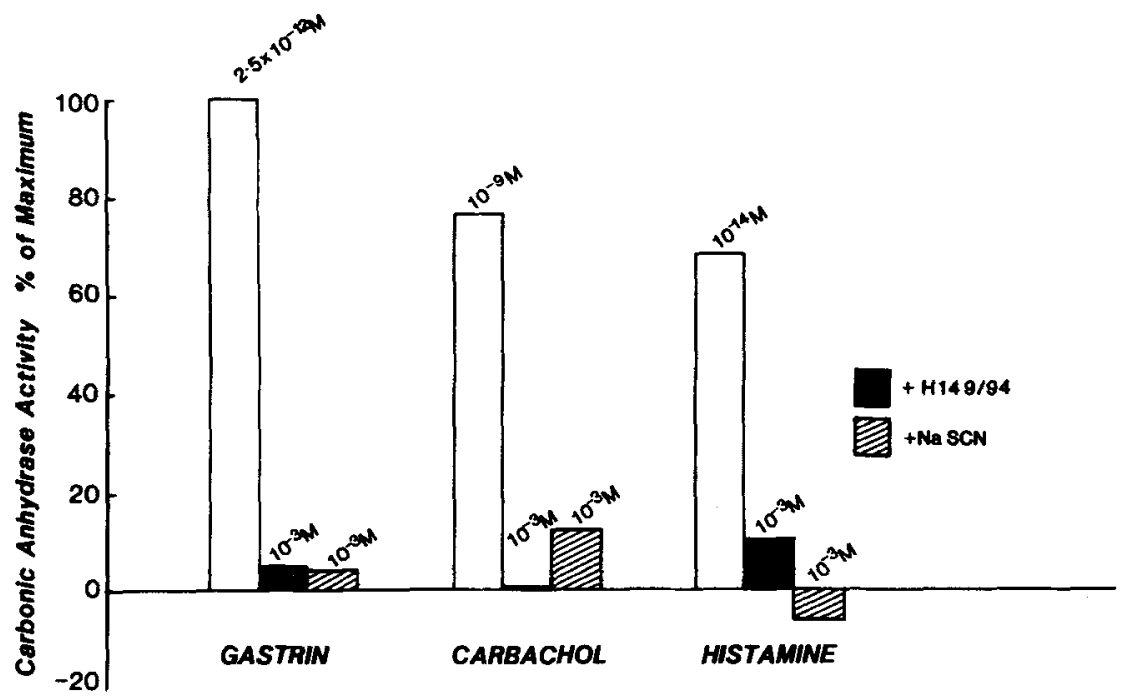

FIGURE 3. Histogram showing mean maximum activation of $\mathrm{CA}$ by the secretagogues, gastrin, histamine, and carbamylcholine and the effects of $\mathrm{NaSCN}\left(10^{-3} \mathrm{M}\right)$ and H149/94 $\left(10^{-3} \mathrm{M}\right)$.

inhibited by the CA inhibitor, acetazolamide. The agonist activities were selectively blocked by respective antagonists. The benzimidazole derivative compound Hassle $149 / 94\left(10^{-3} \mathrm{M}\right)$ abolished the actions of all agonists.

Thus, histamine, gastrin and carbamylcholine have independent actions on oxyntic cell CA. The inhibition of the activity of all three secretagogues by $\mathrm{H} 149 /$ 94 suggests a close link between $\mathrm{CA}$ activity and the functioning of the proton pump $\mathrm{H}^{+}+\mathrm{K}^{+}$-ATPase.

\section{REFERENCES}

1. Maren, T. 1967. Carbonic anhydrase: Chemistry, physiology and inhibition. Physiol. Rev. 47: 597-781.

2. Cross, S. 1970. Ultrastructural localization of carbonic anhydrase in rat stomach parietal cells. Histochemistry 22: 219-225.

3. SugAI, W. \& S. ITo. 1980. Carbonic anhydrase, ultrastructural localization in the mouse gastric mucosa and improvements in the technique. J. Histochem. Cytochem. 28(6)511-525.

4. LonNERHoLm, G. 1977. Carbonic anhydrase in the intestinal tract of the guinea pig. Acta. Physiol. Scand. 99: 53-61.

5. Loveringe, N. 1978. A quantitative cytochemical method for measuring carbonic anhydrase. Histochem. J. 10: 361-372.

6. Shapiro, B., K. Pienta, A. Heldsinger \& A. I. Vinik. 1981. Somatostatin is an agonist and noncompetitive antagonist of gastrin in oxyntic cell function. Endocrinology 109(4): 1117-21.

7. ViniK, A. 1., L. I. KLAFF \& A. Heldsinger. 1979. A comparison of potency of acid secretagogues in the activation of carbonic anhydrase (CA) in guinea pig parietal cells. Clin. Res. 27: 636A. 
8. Walker, W., A. I. Vinik, A. A. Heldsinger \& R. Kaveh. 1983. The role of calcium and calmodulin in activation of the oxyntic cell by histamine and carbamylcholine in the guinea pig. J. Clin. Invest. 72: 955-964.

9. Puscas, I., A. Chiu, G. H. Buzas, L. Voicu, P. Contrasiv, G. Mihalas, L. Veress, M. Chiss, P. Suranyi, M. Domuta, M. Simonca, O. Arcelean, O. PASCU \& M. RoCSIN. 1980. Contributions to the elucidation of gastric acid secretory mechanisms, carbonic anhydrase and histamine $\mathrm{H}_{2}$ receptors. Rev. Roum. Biochem. 17(1): $57-75$.

10. Soll, A. H. 1978. The actions of secretagogues on oxygen uptake by isolated mammalian parietal cells. J. Clin. Invest. 61: 370-380.

11. HERSEY, S. J. 1974. Interactions between oxidate metabolism and acid secretion in gastric mucosa. Biochem. Biophys. Acta 344: 157-203.

12. Fellenius, E., T. Berglindh, G. Sachs, L. Olbe, B. Elander, S. E. Sjostrand \& B. WALLMARK. 1981. Substituted benzimidazoles inhibit acid secretion by blocking the $\mathrm{H}^{+}+\mathrm{K}^{+}$- ATPase. Nature 290: 159-161. 